\title{
The Effect of Transformational Leadership and Professional Competence on Teachers' Performance: The Role of Work Motivation
}

\author{
Supanji $^{1} \quad$ Reni Herawati ${ }^{2 *}$ Siswoyo Haryono ${ }^{2}$ \\ 1.Universitas Perdada Indonesia, Jakarta, Indonesia \\ 2.Universitas Muhammadiyah Yogyakarta. Bantul, Yogyakarta, 55183, Indonesia
}

\begin{abstract}
The purpose of this study was to determine the effect of transformational leadership and professional competence, both partially and simultaneously towards professional competence. It was also to reveal the role of work motivation as a mediating variable. The data analysis method used in the study is Structural Equation Modeling (SEM) with the Analysis of Moment Structure (AMOS) 22.0 program with the sample size of 255 respondents, taken from a population of 852 . The study presented a novelty since most of the study related to competence was in large scopes of competence. This study focused on professional competence in order to get the detailed result. The conclusions are: (1) transformational leadership and professional competence have a significant effect on work motivation, (2) transformational leadership, professional competence, and work motivation have a significant effect on teachers' performance. The following results are: (1) professional competence had the most dominant effect on work motivation, (2) work motivation had the most significant effect on teachers' performance (3) Work motivation is an intervening variable on transformational leadership and professional competence in improving teachers performance. The results of this study illustrated that the professional competencies of each teacher influenced the work motivation of vocational school teachers in Bekasi. Further, the study presented implications that the improvement of teachers' performance at State Vocational Schools in Bekasi could be through enhancing their work motivation due to the significant evidence that the work motivation variable intervened in transformational leadership and also professional competence.
\end{abstract}

Keywords: Transformational Leadership, Professional Competence, Work Motivation, and Performance

DOI: $10.7176 / \mathrm{EJBM} / 12-11-02$

Publication date: April $30^{\text {th }} 2020$

\section{Introduction}

Human resource management is a vital step in education management(Beare, Caldwell, \& Millikan, 2018). Along with the rapid wave of the reformation in education, various efforts to reform the Indonesian education system have shown the out; as a result, several education regulations have emerged to complement and make regulations perfect. The things which are no longer relevant to current needs re eliminated. Education is a significant factor in e building the national character and is very important in shaping the good or bad the human person according to normative measures. , the government is seriously handling the education sector, because, with a sound education system, that the next generation of qualified and able to adapt to the life of society, nation, and state (La Fua, Nurlila, \& Wekke, 2018; Marini, 2017).

A teacher is a critical person in an educational organization. Thus it is very crucial to enhance teacher quality (Herawati, 2019). The teacher is an essential element in the education process. In the process of education in schools, the teacher holds a dual-task, namely as a teacher and educator. As a teacher, the task is providing and facilitating several instructional materials to students, while, as an educator, the teacher has the responsibility to guide and foster the students to become capable, active, creative, and independent human beings. Teaching and educating are the duties and responsibilities of the teacher as a professional. Therefore, professional competence is required. The quality of the teacher is closely related to professional competence (Hakim, 2015; Kunter, Klusmann, et al., 2013).

Meanwhile, the fact that the result of teacher competence assessment in 2012 and 2015 is really below expectation (Kemdikbud, 2012, 2015). Thus, the low quality of teachers in Indonesia is an alarm. Improving teacher professional competence becomes the primary target for education reform (Kunter, Kleickmann, Klusmann, \& Richter, 2013).

The discussion of improving teacher professional will always relate to motivation(Baumert \& Kunter, 2013; Kunter, 2013; Kunter, Klusmann, et al., 2013). Teacher motivation is an aspect that characterizes professional competence. In his research, Kunter concluded intrinsic motivation as a central factor in determining the professional success of teachers. (Kunter, 2013). Related with school management, the effort to improve teacher professional competence through enhancing work motivation, of course, become the responsibility of the school principal. In this case, primary school leadership emerges to be an essential aspect of the investigation.

Transformational leadership is empowering followers to perform effectively by building their commitment 
to new values, developing their skills and beliefs, creating a climate that is conducive to the development of innovation and creativity(Yukl, 2009; Yukl, O'Donnell, \& Taber, 2009). Transformational leadership vis characterized by charisma, inspiration, and intellectual stimulation (Avey, Hughes, Norman, \& Luthans, 2008; Luthans \& Avolio, 2003). Luthans describes charisma as a leader acting as models that play a dominant role for their subordinates; subordinates recognize their dreamers and are eager to match them. These leaders usually have very high moral and ethical standards and can be counted in doing the right thing. Their subordinates and usually place great trust in them. The leader gives a vision and mission to his subordinates. Inspiration is a description of leaders who convey high hopes to their subordinates to inspire them through motivation to commit and become part of the organization's shared vision. In practice, managers use symbols and emotional connections to focus the efforts of group members to achieve more productive work according to their respective interests.

Yulk(2009) states that intellectual stimulation is behavior that increases followers' awareness of problems and influences followers to view problems from a new perspective. This opinion is in line with (Husain 2009) that intellectual stimulation is a process in which leaders increase the awareness of followers to look at problems from a new perspective. Elements of intellectual stimulation can be seen, among others, from the ability of a leader in communicating his hopes, using symbols to focus his efforts, and expressing essential goals in a simple way in which the leader invites subordinates to think in new ways. So it can be said that leaders explore new ideas and creative solutions from employees and always encourage employees to learn and pay attention to new approaches to doing work.

Based on the research result, (Yang 2014) presents a reference for school management to realize the urgency of transformational leadership for improving school management. Further, he encourages principals to apply their transformational leadership in school management practices (Yang, 2014). The results of this study present implications for promoting transformational leadership as the core of leadership because the transformational leadership of principals is critical in school development. The principal's transformational leadership must play a vital role in the management of school improvement (Sun \& Yang, 2014).

Referring to the research results (Yang, 2014), this study presents a novelty by focusing on the investigation of the effects of transformational leadership in a shared model with professional competence towards teacher performance. Based on a theoretical study of the importance of work motivation on performance, the researcher presents work motivation as a mediating variable.

\section{The Development of Hypothesis}

\subsection{The Effect of Transformational Leadership on Work Motivation}

In the business context, leadership has a powerful influence on the course of an organization and its survival (Mangkunegara \& Prabu, 2005). In the era of globalization and free markets, only companies that can make continuous improvements in the formation of competitive advantages will able to grow and develop. Leadership is the ability to convince and encourage others to work together under the leadership as a team to achieve a specific goal (Samsudin \& MM, 2006). Leadership is an activity to influence people to be directed towards achieving organizational goals (Buble, Juras, \& Matić, 2014) Leadership is the ability of a leader, to influence the behavior of others according to their desires in a particular situation(Thoha, 1983). Leadership is a process of influence, which influences the interpretation of events for followers, the choice of goals for groups or bureaucracy, the organization of work activities to achieve these goals, the motivation of followers to achieve goals, maintenance of relationships cooperation and teamwork, as well as obtaining support and cooperation from people who are outside the group or bureaucracy(Yukl, 2009).

Two things are as individual impulses, namely the direction of behavior (work to achieve goals) and the strength of behavior (how strong the individual effort at work) (Rivai, 2010). Motivation is the strength of someone at a level of persistence and enthusiasm in carrying out an activity, both sourced from within the individual itself and from outside the individual (Sansone \& Harackiewicz, 2000; Sukmalana, 2010).

Based on the description above, that the definition of transformational leadership is the ability to influence people in the process of the relationship between superiors and subordinates based on values, beliefs, and assumptions regarding the vision and mission of the organization and self-development towards actual selfactualization. Dimensions and indicators of transformational leadership such as those developed by Luthan(2012): (1) Attributed Charisma, (2) Inspirational Leadership, (3) Intellectual Stimulation, and (4) Individual Sensitivity. Work motivation is an encouragement both from within oneself and from outside that drives a person to carry out work to achieve goals. Dimensions of work motivation: (1) the need for achievement (need for achievement), (2) the need for collaboration/affiliation with others (need for affiliation), (3) the need to have authority/power (need for power)(Herzberg, 2017). Based on the description of the opinions of experts and previous research above, it proposed that there is an influence of transformational leadership on work motivation.

\section{H1: The better the transformational leadership, the better the work motivation.}




\subsection{The Effect of Professional Competence on Work Motivation}

Competence is the ability to carry out a job or task based on skills, knowledge and work attitude required by the job (Walker, Damanpour, \& Devece, 2011). Competence as the ability to carry out something obtained through education and training (Yukl, 2009). The Five essential characteristics of competences are (1) motives or actions towards individual goals, (2) traits: physical characteristics and respondents that are consistent with the situation and information), (3) self-concept: constitutes behavior, values and personal impression of a person), (4) knowledge: information about someone who has a particular field of substance, and (5) expertise or skill: the ability to carry out specific tasks and mentality (Yukl, 2009).

Motivation is the willingness to strive to achieve organizational goals, influenced by the ability to satisfy some individual needs. Motivation, in general, is related to all efforts to achieve goals, while organizational goals can reflect a single interest related to work-related behavior (Champoux, 2017). There are two types of motivational conditions. The first motivation is called an objective situation, that is, goods or circumstances that derive from outside of a person. It is generally categorized by the term incentives or goals to be achieved, while the second is a personal motivational situation, which is a condition contained in a person or often termed as need or need, drive or drive, or motive or desire. Based on the description of the opinions of experts and previous research above, that there is an influence of professional competence on work motivation(Sukmalana, 2010).

\section{H2: The higher the professional competence, the better the work motivation}

\section{3.. The influence of transformational leadership on performance}

Leadership is the ability to convince and encourage others to want to work together under his leadership as a team to achieve a specific goal [8]. Leadership is an activity in guiding a group in such a way as to achieve that goal [1]. Leadership is an activity to influence people to achieve their goals.d towards achieving organizational goals. The definition of transformational leadership is the ability to influence people in the process of the relationship between superiors and subordinates based on values, beliefs, and assumptions regarding the vision and mission of the organization and self-development towards actual self-actualization. Dimensions and indicators of transformational leadership such as: (1) Attributed Charisma, (2) Inspirational Leadership, (3) Intellectual Stimulation, and (4) Individual Sensitivity(Luthans \& Avolio, 2003).

A study indicates there are positive and significant effects of transformational leadership, transactional, and work motivation on employee performance(Sundi, 2013). The opinion of the previous research that transformational and transactional leadership styles cannot be separated, and the two are not conflicting leadership styles. Transformational leadership is crucial and needed by every organization. Organizations need the vision, drive, and commitment formed by transformational leaders(Bass, Avolio, Jung, \& Berson, 2003).

Transformational leadership is the ability to influence people in the process of the relationship between superiors and subordinates based on values, beliefs, and assumptions regarding the vision and mission of the organization and self-development towards actual self-actualization. Dimensions and indicators of transformational leadership such as: (1) Attributed Charisma, (2) Inspirational Leadership, (3) Intellectual Stimulation, and (4) Individual Sensitivity(Luthans \& Avolio, 2003).

Transformational leadership has a significant effect on employee performance(Sundi, 2013). This research result is in line with the statement that transformational leadership has a significant effect on commitment, performance, and job satisfaction (Walumbwa \& Hartnell, 2011). Another research presents the prediction that transformational leadership influences the empowerment of subordinates(Özaralli, 2003). The existence of transformational leaders affects team members feeling empowered. The more they experience empowerment, the more effective the team. Although the application of transformational leadership principles needs to adapt to various countries, a universal transformational leadership style helps employees become leaders who more effectively lead and produce the best performance (Boehnke, Bontis, DiStefano, \& DiStefano, 2003). Transformational leaders can motivate subordinates, which enables them to maintain achievements and achieve revolutionary change(Friedman, Langbert, \& Giladi, 2000). Transformational leadership can truly change followers by encouraging them to see higher goals in the world of work and encourage the achievement of the best performance (Sparks \& Schenk, 2001).

Performance as a result of work in quality and quantity achieved by an employee in carrying out their duties following the responsibilities given to him (Mangkunegara \& Prabu, 2005). Performance is a record of the results obtained from certain job functions or activities during a specified period [6]. Based on the description above, the teacher's performance is a result of the work achieved by the teacher. The dimensions of teacher performance are (1) ability and quality of work results, (2) initiative and creativity, (3) communication, and (4) ability to relate to others. Based on the description of the opinions of experts and previous research above, that there is an influence of transformational leadership on performance(Mitchel \& Lason, 2008).

H3: The better the transformational leadership, the higher the performance 


\subsection{The Effect of professional competence on performance}

Competence is the ability to carry out or carry out a job or task based on skills, knowledge, and work attitude required by the job (Wibowo, 2010). There are five essential characteristics of competences: (1) motives: impulses or actions towards individual goals, (2) traits: physical characteristics and respondents that are consistent with the situation and information. The next characteristics are (1) self-concept: values and personal impression of a person, (2) knowledge: information about someone who has a particular substance area, and (3) expertise: the ability to carry out tasks and certain mentality (Spencer \& Spencer, 2008).

Performance is about doing work, and the result is work achievement. Performance is the result of work that has a strong relationship with the organization's strategic goals, customer satisfaction, and economic contribution (Wibowo, 2010). Performance as a result of work in quality and quantity achieved by an employee in carrying out their duties following the responsibilities given to him (Mangkunegara \& Prabu, 2005). Based on the description above, the teacher's performance is as a result of the work achieved by the teacher. Dimensions of teacher performance variables such: (1) ability and quality of work results, (2) initiative and creativity, (3) communication, and (4) ability to relate to others. Based on the description of the opinions of experts and previous research above it is suspected that there is an influence of transformational leadership on performance(Mitchel \& Lason, 2008)

\section{H4: The better the professional competence, the higher the performance}

\subsection{The effect of work motivation on performance}

Motivation is a desire to strive to achieve organizational goals, influenced by the ability to satisfy some individual needs. Motivation, in general, is related to all efforts to achieve goals, while organizational goals can reflect a single interest related to work-related behavior. The motivation of the teacher influences the quality of performance (Sukrapi, Muljono, \& Purnaningsih, 2014). There are two types of motivational conditions. The first motivation is called an objective situation, that is, goods or circumstances that are outside of a person who is usually categorized by the term incentives or incentives or goals or goals or goals to achieve. In contrast, the second is a personal motivational situation, which is a condition contained in a person or often termed as need or need, drive or drive, or motive or desire.

The teacher's performance is as a result of work achieved by the teacher. The dimensions of teacher performance are (1) ability and quality of work output, (2) initiative and creativity, (3) communication, and (4) ability to relate to others. Based on the description of the opinions of experts and previous research above it is predicted that there is an influence of work motivation on performance

H5: There better the work motivation, the higher the performance

\section{Research Method}

This study uses quantitative research by developing reliable and valid research instruments about the title of the research, namely the influence of transformational leadership and professional competence on work motivation and its implications for the performance of vocational school teachers in Bekasi. The variables of this study consisted of transformational leadership, professional competence, work motivation, and performance, as measured by instruments with a Likert scale of $1-5$. The scale represented a rating from 'strongly disagree' to 'strongly agree.' 255 respondents were purposely selected. Data was collected through face-to-face distribution by researchers.

Structural Equation Modeling (SEM) with AMOS version 20.0 program as used to analyze data and answer hypotheses. All indicators re-tested by the goodness of fit (GOF) technique. The assessment of the questionnaire items was carried out with Confirmatory Factor Analysis (CFA) to examine the relationship between constructs and indicators based on the theory developed. Cronbach's Alpha s also used to test construction reliability.

\section{Result and Discussion}

Hypothesis testing in this study was analyzed using second-order Structural Equation Modeling (SEM) with AMOS version 20.0. The full SEM test results are o Figure 1. Meanwhile, Table 2 explains the assumptions of test results in the development of SEM. Model fit test confirmation on full models that meet the goodness of fit criteria. The model structure is to draw a model of research causality with structural relationships. Goodness of fit test results are as follows: Chi-Square $=522,285$, probability $=0.51, \mathrm{GFI}=0.892, \mathrm{AGFI}=0.872, \mathrm{NFI}=0.929, \mathrm{CFI}=$ $0.993, \mathrm{IFI}=0.993$ and RMSEA $=0.021$. All research criteria already meet the required cut-off value.his shows that the research model is suitable and meets the standard criteria for analyzing and testing the proposed hypothesis (Haryono, 2017). 


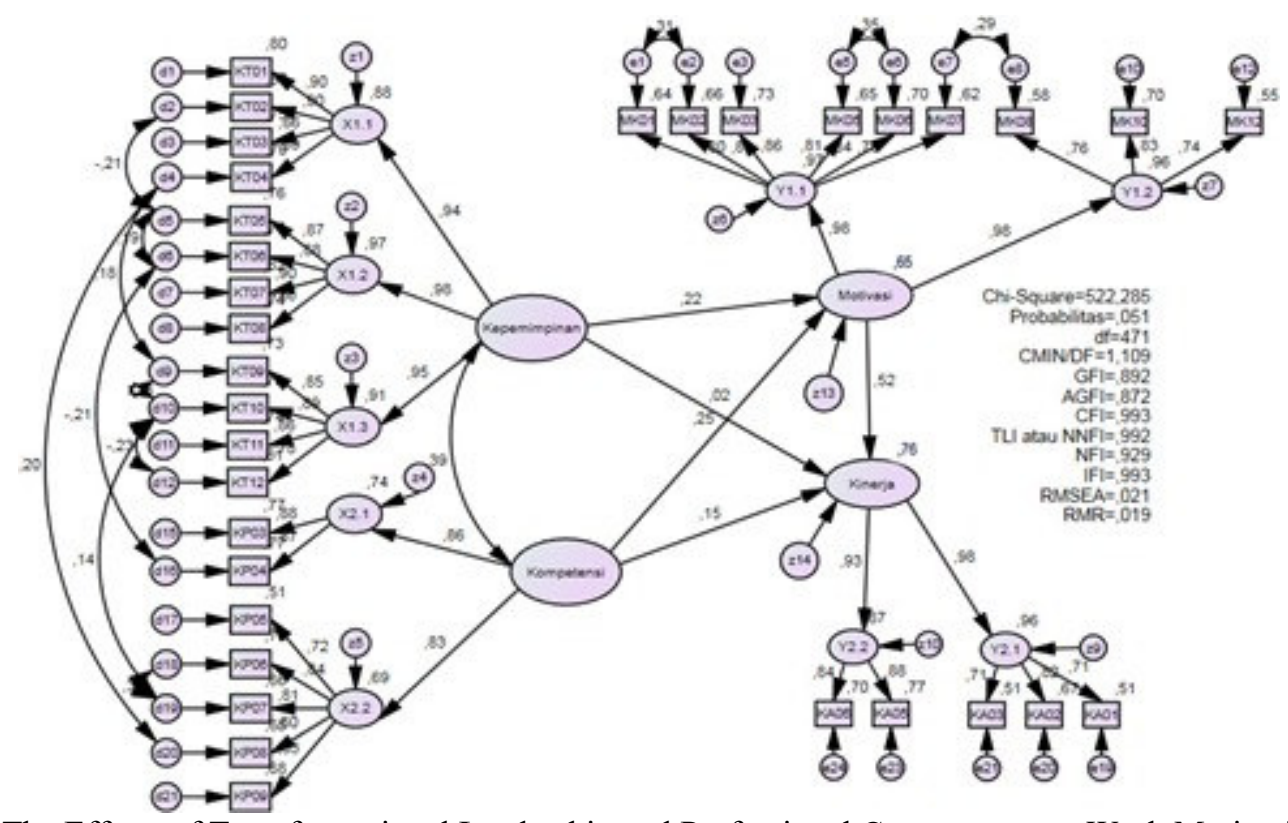

Figure 1. The Effects of Transformational Leadership and Professional Competence on Work Motivation and Its Implications on the Performance of Teachers in State Vocational Schools in Bekasi

Tabel 1. Structural Parameters Estimating Direct Effects: Path Analysis Model

\begin{tabular}{|c|l|c|c|c|}
\hline Hypothesis & \multicolumn{1}{|c|}{ Structural Path } & $\begin{array}{c}\text { Standardized } \\
\text { Path } \\
\text { Coefficients }\end{array}$ & t-Value & Results \\
\hline $\mathrm{H}_{1}$ & Leadership ---> Work Motivation & 0.239 & 3.058 & Significant \\
\hline $\mathrm{H}_{2}$ & Competence ---> Work Motivation & 0.271 & 3.083 & Significant \\
\hline $\mathrm{H}_{3}$ & Leadership ---> Performance & 0.293 & 2.209 & Significant \\
\hline $\mathrm{H}_{4}$ & Competence ---> Performance & 0.193 & 2.005 & Significant \\
\hline $\mathrm{H}_{5}$ & Work Motivation ---> Performance & 0.592 & 6.628 & Significant \\
\hline
\end{tabular}

Based on the first hypothesis testing, there is a positive influence of transformational leadership on the work motivation of vocational school teachers in Bekasi, the magnitude of the influence of transformational leadership on teacher work motivation is $0.239(23.9 \%)$. While the results of hypothesis testing obtained t-statistics obtained values of $3.058 \geq 1.96$ with a confidence level of $95 \%(0.05)$.

The testing of the second research hypothesis shows there is a positive influence of professional competence on the work motivation of State Vocational School teachers in Bekasi, the magnitude of the effect of professional competence on teacher work motivation is $0.271(27.1 \%)$. While based on the results of hypothesis testing, obtained t-statistics of $3.083 \geq 1.96$ with a confidence level of $95 \%(0.05)$.

Based on the third hypothesis testing, that there is a positive influence of transformational leadership on the performance of teachers of State Vocational Schools in Bekasi, the magnitude of the influence of transformational leadership on teacher performance of $0.239(23.9 \%)$. While based on the results of hypothesis testing, obtained tstatistics of $2.209 \geq 1.96$ with a confidence level of $95 \%(0.05)$.

Based on the fourth research hypothesis testing, there is a positive effect of professional competence on the performance of teachers of State Vocational Schools in Bekasi, the magnitude of the effect of professional competence on teacher performance of $0.193(19.3 \%)$. While based on the results of hypothesis testing, obtained t-statistics of $2.005 \geq 1.96$ with a confidence level of $95 \%(0.05)$.

The testing of the fifth research hypothesis shows the positive influence of work motivation on the performance of vocational school teachers in Bekasi, the magnitude of the effect of work motivation on teacher performance is $0.592(59.2 \%)$. While based on the results of hypothesis testing, obtained t-statistics of $6.628 \geq$ 1.96 with a confidence level of $95 \%(0.05)$.

\section{Conclusion}

Based on the research hypothesis testing, that transformational leadership, professional competence, and work motivation partially have a positive and significant effect on performance. Likewise, transformational leadership and professional competence partially affect work motivation.

Based on the results of the study, to enhance the work motivation of teachers of State Vocational Schools in Bekasi based on dimensions, and indicators that have the lowest loading factor coefficient based on work 
motivation variables with a statement of the need for cooperation/affiliation, and freedom in associating with the environment outside the organization. Furthermore, the improvement of competency is congruent with statements of mastery of material, structure, concepts, and scientific mindset that support the subjects taught. The results of this study provide further advice to researchers primarily related to the concept of transformational leadership, professional competency, work motivation variables, and performance variables with a different scope of research, both private and government agencies.

\section{References:}

Avey, J. B., Hughes, L. W., Norman, S. M., \& Luthans, K. W. (2008). Using Positivity, Transformational Leadership, and Empowerment to Combat Employee Negativity. Leadership \& Organization Development Journal. Vol. 29 No. 2, pp. 110-126.

Bass, B. M., Avolio, B. J., Jung, D. I., \& Berson, Y. (2003). Predicting Unit Performance by Assessing Transformational and Transactional Leadership. Journal of applied psychology, 88(2), 207.

Baumert, J., \& Kunter, M. (2013). The COACTIV model of teachers' professional competence Cognitive activation in the mathematics classroom and professional competence of teachers (pp. 25-48): Springer.

Beare, H., Caldwell, B. J., \& Millikan, R. H. (2018). Creating an excellent school: Some new management techniques: Routledge.

Boehnke, K., Bontis, N., DiStefano, J. J., \& DiStefano, A. C. (2003). Transformational Leadership: An Examination of Cross-National Differences and Similarities. Leadership \& Organization Development Journal. Vol. 24 No. 1, pp. 5-15. https://doi.org/10.1108/01437730310457285

Buble, M., Juras, A., \& Matić, I. (2014). The Relationship Between Managers' Leadership Styles and Motivation. Management: journal of contemporary management issues, 19(1), 161-193.

Champoux, J. E. (2017). Organizational Behavior: Integrating Individuals, Groups, and Organizations: Routledge.

Friedman, H. H., Langbert, M., \& Giladi, K. (2000). Transformational Leadership. National Public Accountant, $45(3), 8-11$

Hakim, A. (2015). Contribution of Competence Teacher (Pedagogical, Personality, Professional Competence, and Social) on The Performance Of Learning. The International Journal of Engineering and Science, 4(2), 1-12.

Haryono, S. (2017). Metode Sem untuk Penelitian Manajemen dengan Amos Lisrel PLS (Vol. 1). Jakarta Timur: Luxima Metro Media.

Herawati, R. (2019). Inspirasi Pengawas Sekolah (Inspiration of School Superintendent) (Vol. 1). Yogyakarta: Azyan.

Herzberg, F. (2017). Motivation to Work: Routledge. UK: Transaction Publiser

Husain, U. (2009). Manajemen Praktek, dan Riset Pendidikan. Jakarta: Bumi Aksara.

Kemdikbud. (2012). Hasil Uji Kompetensi Guru 2012. Jakarta: Direktorat Tenaga Pendidik dan Kependidikan.

Kemdikbud. (2015). Hasil Uji Kompetensi Guru Tahun 2015.: Kemdikbud.

Kunter, M. (2013). Motivation as An Aspect of Professional Competence: Research Findings on Teacher Enthusiasm Cognitive activation in the mathematics classroom and professional competence of teachers (pp. 273-289): Springer.

Kunter, M., Kleickmann, T., Klusmann, U., \& Richter, D. (2013). The development of teachers' professional competence Cognitive activation in the mathematics classroom and professional competence of teachers (pp. 63-77): Springer.

Kunter, M., Klusmann, U., Baumert, J., Richter, D., Voss, T., \& Hachfeld, A. (2013). Professional Competence of Teachers: Effects on Instructional Quality and Student Development. Journal of educational psychology, 105(3), 805.

La Fua, J., Nurlila, R. U., \& Wekke, I. S. (2018). The strategy of Islamic Education in Developing Character Building of Environmental Students in Indonesia. Paper presented at the IOP Conference Series: Earth and Environmental Science.

Luthans, F., \& Avolio, B. J. (2003). Authentic Leadership Development. Positive organizational scholarship, 241, 258.

Mangkunegara, A. P., \& Prabu, A. (2005). Evaluasi Kinerja Sumber Daya Manusia. Bandung: Refika Aditama.

Marini, A. (2017). Character Building through Teaching-Learning Process: Lesson in Indonesia. International Journal of Sciences and Research, 73(5), 177-182.

Mitchel, T. R., \& Lason, J. (2008). People in the organization. An introduction to Organizational.

Özaralli, N. (2003). Effects Of Transformational Leadership On Empowerment And Team Effectiveness. Leadership \& Organization Development Journal.

Rivai, V. (2010). dkk, Kepemimpinan dan Perilaku Organisasi: Jakarta: Rajawali Pers.

Samsudin, S., \& MM, M. P. (2006). Manajemen Sumber Daya Manusia, CV. Pustaka Setia, Bandung.

Sansone, C., \& Harackiewicz, J. M. (2000). Intrinsic and Extrinsic Motivation: The Search for Optimal Motivation and Performance: Elsevier. 
Sparks, J. R., \& Schenk, J. A. (2001). Explaining The Effects of Transformational Leadership: An Investigation of The Effects of Higher-Order Motives In Multilevel Marketing Organizations. Journal of Organizational Behavior: The International Journal of Industrial, Occupational and Organizational Psychology and Behavior, 22(8), 849-869.

Spencer, L. M., \& Spencer, P. S. M. (2008). Competence At Work Models For Superior Performance: John Wiley \& Sons.

Sukmalana, S. (2010). Perencanaan SDM(Konsep, Proses, Strategi dan Implementasi). PT Intermedia Personalia Utama. Jakarta. Januari.

Sukrapi, M., Muljono, P., \& Purnaningsih, N. (2014). The Relationship between Professional Competence and Work Motivation with the Elementary School Teacher Performance. Asian Journal of Humanities and Social Studies.

Sun, M., \& Yang, Y. (2014). Principals' Transformational Leadership In School Improvement. International Journal of Educational Management.

Sundi, K. (2013). Effect of Transformational Leadership And Transactional Leadership on Employee Performance Of Konawe Education Department At Southeast Sulawesi Province. International Journal of Business and Management Invention, 2(12), 50-58.

Thoha, M. (1983). Kepemimpinan dalam Manajemen. Jakarta: Badan Litbang Kesehatan Republik Indonesia

Walker, R. M., Damanpour, F., \& Devece, C. A. (2011). Management Innovation and Organizational Performance: The Mediating Effect of Performance Management. Journal of Public Administration Research and Theory, 21(2), 367-386

Walumbwa, F. O., \& Hartnell, C. A. (2011). Understanding Transformational Leadership-Employee Performance Links: The Role Of Relational Identification And Self-Efficacy. Journal of occupational and organizational psychology, 84(1), 153-172.

Wibowo, S. (2010). Manajemen Kinerja-Edisi ketiga, Jakarta: PT. Raja Grafindo Persada.

Yang, Y. (2014). Principals' Transformational Leadership in School Improvement. International Journal of Educational Management, 28(3), 279-288. DOI: 10.1108/IJEM-04-2013-0063

Yukl, G. (2009). Leading organizational learning: Reflections on theory and research. The leadership quarterly, 20(1), Volume 20, Issue 1, February 2009, Pages 49-53.

Yukl, G., O'Donnell, M., \& Taber, T. (2009). Influence of leader behaviors on the leader-member exchange relationship. Journal of managerial psychology. Vol. 24 No. 4, pp. 289-299. https://doi.org/10.1108/02683940910952697 